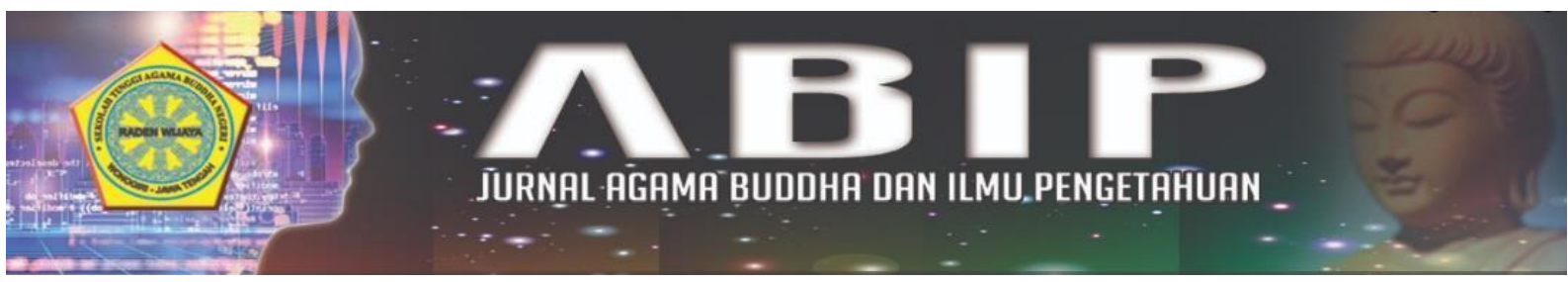

\title{
ANALISIS BAHAN AJAR BAHASA INGGRIS DI SMB DHAMMA PANNA TEMANGGUNG
}

\author{
Oleh: \\ Dwi Maryani Rispatiningsih dan Ayu Lestari \\ PGSD Buddha, STABN Raden wijaya Wonogiri \\ PGSD Buddha, STABN Raden wijaya Wonogiri \\ dwimaryanirispatiningsih2@gmail.com
}

\begin{abstract}
Abstrak
Tujuan penelitian adalah mengetahui dan mendeskripsikan kualitas buku pelajaran Bahasa Inggris. Buku pendamping tersebut dengan judul English Book Elementary School. Secara khusus dilihat dari : a) kelayakan isi; b) kelayakan bahasa; c) kelayakan penyajian; d) kelayakan grafika; dan e) tingkat keterbacaan wacana dalam bahan ajara atau buku text. Penelitian ini merupakan penelitian evaluatif, metode yang digunakan dalam penelitian ini adalah metode penelitian campuran. Subjek yang diteliti berjumlah tiga buku. Hasil penelitian menunjukkan bahwa kelayakan isi, kategori amat baik ada pada KLS 2 dan KLS 3, sedangkan untuk kategori baik di KLS 1. Standar kelayakan kebahasaan, KLS 2 dan KLS 3 kategori baik, KLS 1 memiliki kategori cukup. Segi penyajian berdasarkan isi bahasa kategori amat baik yaitu KLS 2 dan KLS 3 sedangkan untuk KLS 1 mendapatkan kategori baik. Dari segi kegrafisan kategori amat baik dengan urutan KLS 1, KLS 2 dan yang terakhir adalah KLS 3 dengan kategori baik. Pengukuran keterbacaan wacana menunjukkan bahwa ketiga buku Bahasa Inggris yang digunakan di SMB Dhamma Panna Temanggung kurang sesuai dengan jenjang kelas yang diajarkan terutama pada KLS 1 dan KLS 2, sedangkan untuk buku KLS 3 sudah lebih bagus.
\end{abstract}

Kata Kunci : Bahan ajar, Bahasa Inggris, Sekolah Minggu Buddha Dhamma Panna Temanggung

\begin{abstract}
This research objectives was to identify and dscribe the quality of English Textboooks. The companion boook entitled English Book Elementary School. Specially, it's seen from: a) content feasibility; b) language eligibility; c) feasibility of serving; d) Graphic feasibility; and e) the level of readability of the discourse in teaching in teacing materials or text books. This research is evaluative research, the method used in this resarch is mixed methods research. The sbjects of studied were three books. The results showed that the content feasibility, very good category was in KLS 2 and KLS 3, while gor good category in KLS 1. Language eligibility standards, KLS 2 and KLS 3were good categories, KLS 1 had enough categories. In terms of presentation based on the language content, the categories are very good, namely KLS 2 and KLS 3, while for KLS 1 it gets good categoris. In terms of graphics, the categories are very good with the order of KLS 1, KLS 2 and the last is KLS 3 with good categories. The measurement of discourse readability shows that the three English books used in SMB Dhamma Panna Temanggung are not accordance with the class levels taught, especiallly at KLS 1 and KLS 2, while KLS 3 books is better.
\end{abstract}

Keywords: Teaching materials, English, Buddhist Sunday School Dhamma Panna Temnaggung 


\section{PENDAHULUAN}

Salah satu hal terpenting dalam proses belajar mengajar adalah bahan ajar. Menurut Prastowo (2011) bahan ajar merupakan segala bahan (baik informasi, alat, maupun teks) yang disusun secara sistematis, yang menampilkan sosok utuh dari kompetensi yang akan dikuasai peserta didik dan digunakan dalam proses belajar dengan tujuan untuk perencanaan dan penelaahan implementasi dalam pembelajaran. Umumnya bahan ajar yang digunakan dalam proses kegiatan belajar mengajar adalah bahan ajar cetak yaitu buku dan pendukungnya adalah berupa LKS. Buku pelajaran memegang peranan penting dalam kegiatan belajar mengajar dan menyampaikan materi kurikulum dalam mata pelajaran tertentu sehingga menjadi bagian sentral dalam suatu sistem pendidikan. Bahkan buku pelajaran memiliki pengaruh yang besar terhadap prestasi belajar siswa, ini dapat dilihat dalam penelitian yang dilakukan oleh Supriadi (2001), dari studi yang dilakukan terhadap 867 SD dan MI di Indonesia mencatat bahwa tingkat kepemilikan siswa akan buku pelajaran di SD berkorelasi positif dan signifikan dengan hasil belajarnya sebagaimana diukur dengan Nilai Ujian Akhir Nasional. Hal ini berarti bahwa semakin tinggi akses terhadap buku pelajaran, maka semakin tinggi pula hasil belajarnya. Akan tetapi buku pelajaran tersebut harus memiliki kualitas yang baik. Semakin baik kualitas buku pelajaran, maka semakin sempurna pengajaran mata pelajaran yang ditunjangnya.

Buku yang baik adalah buku yang ditulis dengan menggunakan bahasa yang baik dan mudah dimengerti, disajikan secara menarik dilengkapi dengan gambar dan keterangan-keterangannya, isi buku juga menggambarkan sesuatu yang sesuai dengan ide penulisannya (Susetyo, 2010). Dalam pembelajaran bahasa Inggri pun begitu, jika buku pelajarannya bermutu maka akan meningkatlah kualitas pengajaran Bahasa Inggris dan hasil pembelajaran, tentu saja diikuti dengan peningkatan mutu pendidik. Pada dasarnya, sebuah buku pelajaran yang baik adalah buku yang berfungsi sebagai alat pembelajaran yang efektif.
Berdasarkan pengamatan awal dan pencarian awal data yang dilaksanakan pada 9 Agustus via whatapp dengan ketua Vihara Dhamma Panna, buku pendamping tersebut dengan judul English Book Elementary School. Berdasarakan penjelasan ketua Vihara Dhamma Panna, SMB yang ada disana belum begitu aktif dalam pembelajaran Bahasa Inggris. Disini peneliti akan menganalisis buku yang telah dipinjamkan dan akan berupaya mengembangkan bahan ajar untuk guru-guru SMB. Rencana pengembangan bahan ajar tersebut akan peneliti lakukan untuk penelitian selanjutnya, supaya guruguru SMB memiliki beberapa referensi untuk mengajar Bahasa Inggris. Berdasarkan uraian di atas, peneliti ingin melakukan penelitian mengenai kualitas buku pelajaran khususnya mata pelajaran Bahasa Inggris yang digunakan di SMB Dhamma Panna Temanggung, dengan melihat syarat-syarat kelayakan yang harus dipenuhi. Syarat kelayakan tersebut dikaji dari kelayakan isi, kelayakan bahasa, kelayakan penyajian, dan kelayakan kegrafikan, tetapi kelayakan buku tersebut perlu didukung dengan wacana yang sesuai dengan penggunanya sehingga peneliti juga melihat tingkat keterbacaan wacana dalam buku pelajaran.

Berdasarkan uraian diatas maka rumusan dari masalah adalah sebagai berikut bagaimana kualitas buku pelajaran Bahasa Inggris yang digunakan di SMB Dhamma Panna Temanggung yang secara khusus dilihat dari : a) kelayakan isi; b) kelayakan bahasa; c) kelayakan penyajian; d) kelayakan grafika; dan e) tingkat keterbacaan wacana dalam bahan ajara atau buku tersebut?

\section{METODOLOGI PENELITIAN}

Penelitian yang dilakukan ini merupakan penelitian evaluatif. Menurut Sukmadinata (2010) penelitian evaluatif merupakan suatu desain dan prosedur evaluasi dalam mengumpulkan dan menganalisis data secara sistematik untuk menentukan nilai atau manfaat dari suatu praktik. Maka, untuk meneliti fakta-fakta maupun data tersebut dituntut persyaratan yang harus dipenuhi, antara lain yaitu adanya kriteria, tolak ukur atau standar yang digunakan sebagai pembanding bagi data yang telah diperoleh, 
setelah data diolah dan merupakan kondisi nyata dari objek yang diteliti hal inilah yang ditekankan dalam penelitian evaluatifnya (Arikunto, 2010).

Adapun tujuan dari penelitian evaluatif ini untuk mengetahui keterlaksanaan kebijakan, sehingga jika memiliki kelemahan dapat segera diperbaiki. Tujuan akhir dari penelitian ini adalah untuk meningkatkan mutu dari implementasi kebijakan (Arikunto, 2010). Penelitian evaluatif menggunakan pendekatan kuantitatif dan kualitatif dalam pelaksanaannya yaitu menguraikan, mengembangkan, mengilustrasikan, menjelaskan hasil yang diperoleh dari satu metode dengan metode yang lainnya.

Adapun langkah-langkah penelitian evaluatif menurut Arikunto (2010) antara sebagai berikut : (1) identifikasi komponen; (2) identifikasi indikator; (3) identifikasi bukti-bukti; (4) menentukan sumber data; (5) menentukan metode pengumpulan data; (6) menentukan instrumen pengumpulan data.

Penelitian ini menggunakan metode deskriptif (Evaluaive Study) yang dilakukan untuk menilai, mengetahui kualitas objek apakah objek yang diteliti sudah sesuai, kurang sesuai, atau tidak sesuai dengan kriteria (Arikunto, 2010) yang mana dalam penelitian ini berupa buku teks yang dilakukan secara objektif atau apa adanya.

Selain itu karena menggunakan penelitian evaluatif, maka metode yang digunakan dalam penelitian ini adalah mixed Methods Research. mixed Methods Research adalah metode yang digunakan dalam melakukan suatu evaluasi menggunakan metode penelitian campuran atau kombinasi metode kuantitatif dan metode kualitatif secara bersamaan dalam satu proses evaluasi (Wirawan, 2012). Diharapkan hasil dari penelitian ini tidak hanya sekedar menjawab berkualitas atau tidak, sesuai atau tidak, tetapi juga menjelaskan apa sebab dan alasan sehingga memberikan jawaban.

Keterbatasana dalam penelitian ini adalah bersifat subjektif, katena itu untuk mendapatkan hasil yang lebih valid, dilakukan keabsahan hasil data menggunakan teknik triangulasi. Teknik triangulasi yang digunakan berupa triangulasi penyidik, yaitu dengan memanfaatkan peneliti atau pengamat lainnya untuk keperluan pengecekan kembali deraajt kepercayaan data atau dengan membandingkan hasil pekerjaan seorang analis dengan analis lainnya (Moleong. 2007). Data hasil analisis masing-masing pengamat didiskusikan dalam FGD supaya memperoleh sebuah kesimpulan. Kesimpulan tersebut untuk mendiskripsikan kualitas buku pelajaran yang digunakan di SMB Dhamma Panna Temanggung.

\section{HASIL}

Hasil analisis yang dilakukan oleh peneliti dari 4 aspek kelayakan tersebut dan pengukuran tingkat terbacaan wacana adalah sebagai berikut:

\section{Kelayakan Isi}

Hasil analisis yang telah dilakukan oleh peneliti berdasarkan penilaian kelayakn isi, yang terdiri dari atas kesesuaian uraian materi dengan SK, KD, keakuratan materi, dan materi pendukung sebagai berikut:

\begin{tabular}{|c|c|c|c|c|}
\hline $\begin{array}{c}\text { Sub } \\
\text { komponen }\end{array}$ & Butir & KLS 1 & KLS 2 & KLS 3 \\
\hline \multirow{3}{*}{$\begin{array}{l}\text { Kesesuaian } \\
\text { uraian } \\
\text { materi } \\
\text { dengan SK } \\
\text { dan KD }\end{array}$} & $\begin{array}{l}\text { Kelengkapa } \\
\text { n materi }\end{array}$ & 2 & 2 & 3 \\
\hline & $\begin{array}{l}\text { Kedalaman } \\
\text { materi }\end{array}$ & 2 & 1 & 2 \\
\hline & $\begin{array}{l}\text { Pilihantema } \\
\text { kelas 1-3) }\end{array}$ & 1 & 3 & 4 \\
\hline \multirow[t]{2}{*}{$\begin{array}{l}\text { Keakuratan } \\
\text { materi }\end{array}$} & $\begin{array}{l}\text { Keakuratan } \\
\text { fakta dan } \\
\text { konsep }\end{array}$ & 2 & 4 & 4 \\
\hline & $\begin{array}{l}\text { Keakuratan } \\
\text { ilustrasi }\end{array}$ & 1 & 4 & 4 \\
\hline \multirow{4}{*}{ Pendukung } & $\begin{array}{l}\text { Kesesuaian } \\
\text { perkembang } \\
\text { an ilmu }\end{array}$ & 3 & 4 & 3 \\
\hline & $\begin{array}{l}\text { Keterkinian } \\
\text { contoh, dan } \\
\text { rujukan }\end{array}$ & 4 & 4 & 3 \\
\hline & Kontekstual & 3 & 4 & 4 \\
\hline & \multirow[t]{2}{*}{$\begin{array}{l}\text { Salingtemas } \\
\text { lingkungan, }\end{array}$} & 1 & 3 & 3 \\
\hline Total & & 19 & 29 & 30 \\
\hline \multicolumn{2}{|l|}{ Nilai } & 52.77 & 80.55 & 83.33 \\
\hline \multicolumn{2}{|l|}{ Rata-rata } & \multicolumn{3}{|c|}{72.21} \\
\hline $\begin{array}{l}\text { Tabel } 1 . \\
\text { Pelajaran } \\
\text { Berdasarkan }\end{array}$ & $\begin{array}{lr}\text { Daftar } & \text { Has } \\
\text { Bahasa } & \text { Ing } \\
\text { Isi } & \end{array}$ & ${ }_{\text {ris }}$ An & $\begin{array}{l}\text { alisis } \\
\text { Kelas }\end{array}$ & $\begin{array}{r}\text { Buku } \\
1,2,3\end{array}$ \\
\hline
\end{tabular}


Dari tabel diatas dapat diketahui bahwa hasil penilaian instrumen Elementary School Grade 1 untuk kelas 1 dengan total nilai 19 dari 36 (52.77) dengan kategori baik, buku yang kedua yaitu Elementary School Grade 2 untuk kelas 2 dengan total nilai 29 dari 36 (80.55) dengan kategori amat baik, dan buku yang terakhir yaitu judul buku Elementary School Grade 3 untuk kelas 3 dengan total nilai 30 dari 36 (83.33 dengan kategori amat baik). Buku yang mendapatkan hasil skala cukup maka perlu diperbaiki untuk bagian isinya karena nilai 50 lebih sedikit. Nilai rata-ratanya sendiri adalah 72.21 yang menunjukkan bahwa kedua buku yaitu KLS 2 dan KLS 3 berada diatas rata-rata dan satu buku yaitu buku KLS 1 berada dibawah ratarata.

Dari penilaian isi, terdapat tiga komponen berdasarkan BNSP yang dinilai dalam sembilan sub komponen. Komponen tersebut adalah kesesuaian uraian materi dengan SK dan KD, keakuratan materi, dan materi pendukung pembelajaran. Khusus untuk sub komponen kesesuaian uraian materi dengan SK dan KD dan juga keakuratan materi menggunakan lembar kerja terlampir untuk menilai butir-butirnya.

Data kesesuaian SK dan KD kurikulum 13 dengan buku pelajaran KLS 1 diketahui bahwa ada 5 materi yang sesuai dari total 10 materi yang berada di buku. Sedangkan yang tidak sesuai dengna SK dan KD ada 5 materi. Materi yang sesuai dengan SK dan KD hanya mencakup 4 ranah keterampilan yaitu keterampilan mendengarkan, berbicara, membaca dan menulis. Materi yang dapat meningkatkan keterampilan menyimak yaitu pada materi ke 1 dan 7. Pada materi tersebut setandar kompetensi yang akan dicapai yaitu "Memahami instruksi sangat sederhana dengan tindakan dalam konteks kelas". Dengan kompetensi Dasar adalah "Merespon dengan kosa kata baru dengan ucapan lantang" Kegiatan pembelajarannya adalah siswa mendengarkan guru menyebutkan macam-macam jenis hewan kemudian siswa mengulang apa yang telah disampaikan oleh guru. Penugasan siswa mendengarkan kemudian menuliskan di lembar kerja masingmasing.
Sedangkan untuk keterampilan berbicara terdiri dari 1 materi. Dengan kegiatan pembelajaran di depan kelas tentang tindak tutur. Adapun SK adalah "Mengungkapkan informasi sangat sederhana dalam konteks kelas" dengan kompetensi dasar adalah "bercakap-cakap untuk meminta/memberi informasi secara berterima yang melibatkan tindak tutur : mananyakan suatu benda atau menanyakan orang". Kegiatan yang dilakukan didalam kelas adalah menanyakan suatu benda juga menanyakan seseorang baik itu kesukaan dari orang tersebut. Untuk latihan soal yang diberikan dalam materi ini adalah menanyakan favorit dari orang lain baik itu makanan, nomer, maupun jenis hewan. Adapaun materi berbicara yang telah diberikan sesuai dengan SK dan KD yang telah ditetapkan oleh pemerintah. Dalam materi ini, siswa diberikan soal untuk menjawab dar pertanyaan yang bersifat pribadi. Contoh pertanyaan yang ditanyakan antara lain adalah favorit nomor, favorit makanan, minuman, acara TV dan lain sebagaimnya.

Terdapat 1 materi yang sesuai untuk kompetensi menulis yaitu pada chapter 5 mempelajari tentang kata kerja. Adapun SK dari materi ini adalah "Mengeja dan menyalin tulisan Bahasa Inggris sangat sederhana dalam konteks kelas". Kompetensi dasar dari materi ini adalah "mengeja kosakata Bahasa Inggris sangat sederhana secara tepat dan berterima dengan ejaan yang benar". Dalam penugasan didalam kelas siswa diminta untuk menuliskan aktifitas yang dilakukan oleh orang yang ada di dalam gambar. Contoh gambar dari materi menulis yang sesuai dengan Sk dan KD

Dalam materi tantang keterampilan membaca yang sesuai dengan SK dan KD ada 1 materi yaitu pada chapter 2. Adapun pada chapter ini membahas terkait percakapan sehari-hari ysitu tentang "greeting" atau salam. Adapun SK dan KD dalam keterampilan membaca adalah "Memahami tulisan Bahasa Inggris sangat sederhana dalam konteks kelas" sedangkan KD nya adalah "membaca nyaring dengan ucapan dan intonasi yang tepat dan berterima yang melibatkan kata, frase, dan kalimat sangat 
sederhana". Dalam pembelajaran didalam kelas siswa dan guru membacakan text yang ada dalam buku kemudian untuk materinya adalah siswa menjawab pertanyaan yang sesuai dengan text yang telah diberikan dan juga mengartikan atau menerjemahkan dalam bahasa indonesia.

Materi yang tidak sesuai dengan SK dan KD berjumlah 5 materi. Kebanyakan dari materi ini adalah yang seharusnya lebih menekankan kepada skill berbicara atau pelafalan, tetapi dalam buku ini sangat menekankan akan menulis semata. Seperti contoh pada chapter 3 membahas tentang angka. Dalam pembelajarannya lebih menekankan pada menulis. Seharusnya untuk kelas rendah lebih menekankan pada skill berbicaranya terlebih dahulu, tetapi dalam buku ini skill yang lebih dominan adalah menulis. Materi yang ada dalam buku ini tidaklah lengkap, materi juga tidak dibahas secara mendalam. Dalam latihan soalpun bahasa yang digunakan secara berulangulang. Jika para guru meggunakan buku ini, sebaiknya mencari referensi tambahan supaya materi yang disampaikan lebih mendalam.

Data kesesuaian SK dan KD kurukulum 2013 dengan buku pelajaran Bahasa Inggris yang digunakan di SMB Dhamma Sekha dengan judul buku English Book Elementary School Grade 1 menunjukkan bahwa materi yang sesuai dengan SK dan KD memiliki jumlah yang sama dengan materi yang tidak sesuai dengan SK dan KD untuk kelas 1. Materi yang sesuai dengan SK dan KD di dominasi pada keterampilan menyimak atau mendengarkan.sedangkan materi yang tidak sesuai dengan SK dan KD di dominasi oleh keterampilan menulis yang seharusnya merupakan keterampilan berbicara, adapun penjelasannya sebagai berikut:

Dalam keterampilan mendengarkan atau menyimak ada pada chapter 1 dan chapter 7 , untuk bahasannya yang dibahas tiap chapter adalah "personal idintity" dan macam-macam hewan. Untuk keterampilan berbicara hanya pada chapter 8 yaitu tentang tanya jawab yang menjadi favorit baik makanan, acara TV maupun sampai pada hewan. Materi yang sesuai dengan SK dan KD membaca hanya terdiri dari 1 materi saya yaitu pada chapter 2. Dalam materi ini mempelajari tentnag greeting dalam sebuah percakapan. Secara keseluruhan, materi yang ada dalam buku ini sangat minim sekali dan bila digunakan oleh guru sebaiknya mencari referensi tambahan.

Materi yang tidak sesuai dengan SK dan KD kelas 1 berjumlah 5 materi. Ketidak seuaian materi tersebut lebih menekankan keterampilan menulis dari pada berbicara maupun membaca. Seperti pada chapter 3, materi tersebut lebih menuntut keterampilan menulis dari pada membaca maupun berbicara. Padahal yang paling banyak adalah materi tentang angka. Dalam buku ini instruksi yang diberikan oleh penulis sangatlah sedikit sekali, lebih banyak menekankan pada latihan-latihan soal.

Data kesesuaian SK dan KD kurikulum 13 dengan buku pelajaran dengan judul English Book Elementary School Grade 2 dengan kode KLS 2 menunjukkan di buku ini jumlah materi yang sesuai dengan SK dan KD ada 5 materi sedangkan yang tidak sesuai ada 1 materi saja. Materi yang sesuai dengan SK dan KD pada keterampilan mendengarkan di buku ini tidak ada. Untuk keterampilan berbicara ada 1 materi yang sesuai dengan Sk dan KD yaitu pada chapter 2. Materi yang dijabarkan di chapter 2 in membahas tentang daily activity atau dalam bahasa indonesia adalah kegiatan sehari-hari. Dimana materinya menjabarkan tentang kegiatan sehari-hari yang sering dilakukan oleh anak pada umumnya dan juga membahas terkait waktu. Untuk latihan soal yang penulis buku gunakan disini adalah menerjemahkan dalam Bahasa Inggris apa yang ada dalam gambar untuk latihan soal dalam materi waktu disini lebih menanyakan jenis kegiatan yang dilakuakn pada siang/sore/pagi harinya. Kedalaman materi yang diberikan dalam buku ini lebih bagus dari pada KLS 1. Adapun SK dan KD dari keterampilan berbicara adalah sebagai berikut : SK "mengungkapkan informasi sangat sederhana dalam konteks sekitar peserta didik" dan untuk KD nya adalah "bercakap-cakap untuk meminta/memberi informasi secara berterima yang melibatkan tindak tutur:menanyakan suatu benda, menanyakan dimana benda berada, dan menanyakan jumlah benda". 
Untuk KD kedua yaitu "bercakap-cakap untuk menyertai tindakan secara berterima yang melibatkan tindak tutur:menyebutkan usia, tanggal lahir, serta menyebutkan waktu".

Dalam buku ini, untuk keterampilan membaca ada 1 materi yaitu pada chapter 5 . Adapaun SK dan KD dari keterampilan membaca adalah "Memahami tulisan Bahasa Inggris sangat sederhana dalam konteks sekitar peserta didik. Untuk KD dalam keterampilan membaca adalah "membaca nyaring dengan mengucapkan dan intonasi yang tepat dan berterima yang melibatkan kata, frase maupun kalimat yang sederhana". Untuk KD yang kedua yaitu "memahami kalimat teks deskriptif bergambar sangat sederhana secara tepat dan berterima". Dalam chapter 5 ini membahas akan family dan diskripsi dari keluarga dalam text yang telah disediakan. Untuk latihan soal yang diberikan penulis buku adalah tentang mendiskripsikan keluarga peserta didik sendiri.

Terakhir adalah keterampilan menulis yang dalam buku ini ada 2 materi yaitu pada chapter 1 dan 3. Adapun SK dan KD dari keterampilan menulis adalah sebagai berikut : "Mengeja dan menyalin tulisan Bahasa Inggris sangat sederhana dalam konteks sekitar peserta didik". Untuk KD nya dalah" mengeja kosa kata Bahasa Inggris sangat sederhana secara tepat dan berterima dengan ejaan yang benar". Yang kedua adalah "menyalin kosakata Bahasa Inggris sangat sederhana secara tepat dan berterima". Dalam materi chapter 1 membahas terkait macammacam expresi yang ada disekitar kita. Untuk latihan soal yang diberikan oleh penulis adalah mengisi kata yang sesuai dengan soal atau melengkapi kalimat rumpang. Sedangkan untuk chapter 3 membahas tentang bendabenda disekitar rumah. Macam-macam benda yang ada di kamar tidur, benda yang ada di dapur dan lain sebagainya. Untuk soal yang diberikan oleh penulis kepada peserta didik adalah berupa soal yang mengisi kata yang tidak ada dalam kalimat atau menjodohkan. Adapaun contoh dari materi terkait keterampilan menulis adalah sebagai berikut:

Jumlah materi yang tidak sesuai dengan SK dan KD pada buku KLS 2 ini ada 1 materei. Yaitu pada materi terakhir. Dalam materi ini menekankan akan keterampilan menulis semata padahal dalam kenyataannya keterampilan yang digunakanbisa keterampilan berbicara. Dalam bab ini ada sebuah lirik nyanyian tetapi dalam kenyataannya menekankan materi menulis, begitu juga dengan soal-soal yang telah diberikan, lebih banyak menggunakan keterampilan menulis. Dari materinya yang berupa nyanyian bisa diambil beberapa latihan untuk para siswa, tetapi ternyata soal yang diberikan ini tidak sesuai dengan materi menyanyi yang ada diatas.

Data kesesuaian buku dengan judul English Book Elementary School Grade 3 dengan standar kompetensi dan kompetensi dasar menunjukkan bahwa materi yang sesuai dengan SK dan KD berjumlah 6 materi, lebih banyak dari pada materi yang tidak sesuai dengan SK dan KD yang berjumlah 1 materi. Materi yang sesuai tersebut adalah terdapat 1 materi yang sesuai dengan SK dan KD dalam keterampilan mendengarkan, yaitu pada pembelajaran 1 submateri 1 yang mana membicarakan tentang my day atau dalam bahasa indonesia adalah hariku. Dalam hal ini guru dibantu dengan media tape recorder atau bisa juga melalui HP. Tugas dari para siswa yaitu mengisi kerumpangan dalam wacana yang telah tersedia. Adapaun SK dan KD dari keterampilan mendengarkan adalah sebagai berikut "memahami instruksi sangat sederhana dengan tindakan dalam konteks sekolah" sedangkan untuk kompetensi dasarnya antara lain: "merespon dengan mengulang kosakata baru dengan ucapan lantang" dan "merespon dengan melakukan tindakan sesuai instruksi secara berterima". Dalam kaitannya dengan materi ini kesesuaian dengan KD terutama pada kompetensi dasar yang ke 2 .

Untuk keterampilan membaca dalam buku ini terdiri dari 3 materi, yaitu pada chapter 1, 6 dan 7. Adapun standar kompetensinya dalah "memahami tulisan bahas inggris sangat sederhana dalam konteks sekolah, dan untuk kompetensi dasarnya adalah" membaca nyaring dengan ucapan dan intonasi yang tepat dan berterima yang melibatkan kata, frase, dan kalimat sangat sederhana" yang kedua "memahami kalimat dan text deskriptif bergambar sangat sederhana secara tepat dan berterima. Dalam 
chapter 1 membahas akan kegiatan sehari hari yang dilakukan dalam konteks kegiatan di rumah. Kemudian pada chapter 6 mendiskripsikan tentang diri sendiri atau memperkenalkan diri sedangkan pada chapter 7 membahas akan my friend, Rio. Dimana dalam materi ini mendiskripsikan seorang teman yang bernama Rio. Untuk latihan soal yang penulis beriakn sangat relevan dengan pembahasan sebelumnya atau pada bacaan. Soal-soal yang diberikan adalah mengacu dari text yang sebagai materi. Selain menjawab pertanyaan tentang isi text, penulis juga memberikan soal tentang benar atau salah dari statmen yang ada di bacaan. Berikut ini merupakan salah satu contoh dari keterampilan membaca yang ada dalam buku English Book Elemantary School Grade 3.

Sedangkan keterampilan menulis terdiri dari 1 materi yang berada pada chapter 5. Adapun Standar Kompetensi dan Kompetensi dasar dari keterampilan menulis adalah "mengeja dan menyalin tulisan Bahasa Inggris sangat sederhana dalam kontekks sekolah" untuk kompetensi dasarnya adalah "mengeja kosa kata Bahasa Inggris sangat sederhana secara tepat dan berterima dengan ejaan yang benar" yang kedua "menebalkan kosakata Bahasa Inggris sangat sederhana secara tepat dan berterima". Dalam materi keterampilan menulis ini membahas akan jenis-jenis warna. Soal latihan yang diberikan pun terkait warna dan aplikatif dalam kehidupan sehari-hari.

Untuk keterampilan berbicara ada pada chapter 3 dan 4 dalam buku English Book elemantary school grade 3 KLS 3. Adapun standar kompetensinya adalah "Mengungkapkan informasi sangat sederhana dalam konteks sekolah" sedangakan untuk kompetensi dasar adalah "bercakap-cakap untuk meminta dan memberi informasi secara berterima yang melibatkan tindak tutur: memperkenalkan diri, menanyakan kepemilikan, menanyakan kegiatan yang sedang dilakukan seseorang”. Untuk kompetensi dasar yang kedua adalah "bercakap-cakap untuk meminta/memberi informasi secara berterima yang melibatkan tindak tutur: menyebutkan nama-nama benda, menyebutkan dimana seseorang berada, dan menyebutkan kesukaan dan kepunyaan".
Dalam chapter 3 membahas terkait diskripsi dari hewan dan juga ciri-cirinya. Sedangkan untuk soalnya yang digunakan oleh penulis adalah translate, dan juga puzzle. Untuk chpter 4 penulis buku ini menekankan keterampilan berbicara. Adapun materi yang disampaikan pada chapter 4 ini adalah terkait pekerjaan dan juga menyusun kalimat dengan personal informasi. Tidak ada pendalaman materi ataupun soal-soal yang tersedia pada chapter ini. Dalam hal ini di chapter 4 ini menekankan akan KD yang pertama.

Dalam materi yang tidak sesuai dengan SK dan KD kelas 3 ada 1 materi yaitu pada chapter 2. Dalam chapter 2 ini membahas dengan tema waktu. kemampuan keterampilan yang digunakan yaitu menulis. Padahal seharusnya keterampilan yang digunakan adalah berbicara dimana materi baawahnya mendukung untuk kemampuan berbicara yaitu tentang bernyanyi bersamasama.

Secara keakuratan materi terdiri ats keakuratan fakta dan konsep; dan keakuratan ilustrasi. Untuk keakuratan materi dapat dilihat pada kesesuaian SK dan KD terlampir. Sedangkan untuk keakuratan ilustrasi, dinilai dari fungsi ilustrasi tersebut sebagai bagian dalam materi dan keakuratannya (seperti ukuran dan bentuk proposional, serta keterangan yang tepat), dapat dilihat bahwa ilustrasi diberikan oleh penulis buku sesuai dengan materi yang diberikan, misalnya dalam materi yang menekankan kemampuan berbicara dimana di buku KLS 3 ada gambar yang medukung para siswa untuk mempermudah siswa lebih memahami. Ilustrasi yang diberikan pun sesuai dengan yang dipelajari. Misalnya gambar guru maka ilutrasi yang digunakan adalah gambar guru begitu juga dengna dokter, perawat dan juga polisi. Tetapi ada juga bentuk ilustrasi yang kurang sesuai proporsional, misalnya pada buku KLS 2 halaman 3 ilustrasi yang diberikan sangatlah kecil shingga kurang jelas dan juga ilustrasi sangat banyak dan berjubel seperti tidak efektif. Pada buku ini juga ada ilutrasi yang berwarna hitam putih dengan sebagian besar ilustrasi berwujud kartun, sehingga terkesan tidak konstektual seperti pada halaman yang lain. 
Sedangkan pada buku KLS 1 beberapa ilustrasi sudah sesuai dengan materi, misalnya tentang belajar angka ada pada chapter 3 halaman 5. Dimana angka-angka tersebut sudah proporsional dan juga berwarna sehingga anak tidak jenuh dalam belajar. Dalam buku KLS 1 ini ada juga sebagian yang tidak masuk akal atau tidak kontekstual misalnya gambar mata yang digunakan adalah ilustrasi gambar mata dan gigi tetapi berupa animasi yang kurang relevan dengan gambargambar yang lainnya. Dimana gambargambar yang lainnya merupakan gambar nyata bukanlah gambar animasi. Dari ketiga buku ini kesemunya tidak dilengkapi dengna sumber tahun rujukan, daftar pustakapun tidak disertai oleh penulis buku.

\section{Kelayakan Bahasa}

Kelayakan bahasa adalah penggunaan bahasa yang baik dan benar di dalam buku, baik sesuai dengan kondisi dan perkembangan anak. Sedangkan benar bahwa bahasanya masih berlandaskan tata bahasa dan EYD. Hasil penilaian bahasa disajikan dalam tabel berikut:

\begin{tabular}{|c|c|c|c|c|}
\hline \begin{tabular}{c|} 
Sub \\
komponen
\end{tabular} & Butir & KLS 1 & KLS 2 & KLS 3 \\
\hline \multirow{2}{*}{$\begin{array}{l}\text { Kesesuaian } \\
\text { dengan } \\
\text { tngkat } \\
\text { perkembang } \\
\text { an peserta } \\
\text { didik }\end{array}$} & $\begin{array}{l}\text { Kesesuaian } \\
\text { Berpikir }\end{array}$ & 1 & 3 & 4 \\
\hline & $\begin{array}{l}\text { Kesesuaian } \\
\text { sosial }\end{array}$ & 3 & 3 & 3 \\
\hline \multirow{3}{*}{$\begin{array}{l}\text { Komuni- } \\
\text { katif }\end{array}$} & $\begin{array}{l}\text { Keterpaham } \\
\text { an pesan }\end{array}$ & 1 & 3 & 3 \\
\hline & $\begin{array}{l}\text { Ketepatan } \\
\text { tata bahasa } \\
\text { dan ejaan }\end{array}$ & 3 & 4 & 3 \\
\hline & $\begin{array}{l}\text { Kebakuan } \\
\text { istilah dan } \\
\text { simbol- } \\
\text { simbol }\end{array}$ & 3 & 3 & 3 \\
\hline \multirow{2}{*}{$\begin{array}{l}\text { Keruntuta } \\
\mathrm{n} \text { dan } \\
\text { kesatuan } \\
\text { gagasan }\end{array}$} & $\begin{array}{l}\text { Keutuhan } \\
\text { dan paragraf }\end{array}$ & 1 & 2 & 2 \\
\hline & $\begin{array}{l}\text { Ketertautan } \\
\text { antar bab, } \\
\text { sub-bab, } \\
\text { paragraf, } \\
\text { dan kalimat }\end{array}$ & 1 & 1 & 1 \\
\hline \multicolumn{2}{|l|}{ Total } & 13 & 19 & 19 \\
\hline \multicolumn{2}{|l|}{ Nilai } & 46,43 & 67,85 & 67,85 \\
\hline \multicolumn{2}{|l|}{ Rata-rata } & \multicolumn{3}{|c|}{60.71} \\
\hline
\end{tabular}

Tabel 2 Daftar Hasil Analisis Buku Pelajaran Bahasa Inggris kelas 1,2,3 Berdasarkan Bahasa

Hasil penilaian pada instrumen ke 2, penilaian kebahasaaan dari ketiga buku ini adalah sebagai berikut ini untuk buku KLS 1 scor nya dalah 13 dari $28(46,43)$ kategori cukup. Buku yang kedua yaitu dengan kode KLS 2 denengan nilai 19 dari 28 (67.85) dengan kategori baik, sedangkan buku yang terakhir dengan kategori KLS 3 dengan nilai 19 dari 28 (67.85) dengan kategori baik. Adapun rata-rata dari ketiga buku ini adalah 60,71 .

Kelayakan bahasa dari 3 komponen yaitu kesesuaian dengan tingkat perkembangan peserta didik, komunikatif, keruntutan dan kesatuan gagasan. Untuk tingkat perkembangan peserta didik, dalam buku KLS 1 pada butir 1 kesesuaian dengan tingkat berpikir berpikir secara umum jumlah kata dalam kalimat 4-7 kata. Untuk bahasanya cukup sulit dipahami bagi siswa kelas 1 karena banyak menggunakan Bahasa Inggrisnya. Seharusnya untuk kelas 1 bahasa yang digunakan haruslah sesederhana mungkin dan banyak ilustrasinya. Dan masih menggunakan bahasa indonesia. Sedangkan untuk perkembangan sosialnya buku ini menimbulkan rasa senang karena buku lebih membujuk siswa, mengaitkan hal-hal yang terdapat dalam buku dengan pengalaman siswa, sehingga siswa tertarik untuk mengikuti pembelajaran.

Untuk buku dengan kode KLS 2 secara umum jumlah kata terdiri dari 5-8 Kata dalam satu kalimat. Kata-kata yang digunakan kesemuanya dalam bentuk Bahasa Inggris, akan tetapi untuk soal yang diberikan kepada siswa ada soal yang menggunakan bahasa indonesia tetapi disuruh mentranslate dalam Bahasa Inggris.

Buku yang ketiga yaitu dengan kode KLS 3 secara umum kata terdiri dari 2-10 kata dalam satu kalimat. Bahasa yang digunakan dalam buku ini padat dan kalimat yang bersifat perintah. Dalam buku ini tidak ada kalimat yang bersifat mengajak, sedangkan di dua buku yaitu buku KLS 1 dan KLS 2 ada kalimat yang bersifat mengajak. Dalam ketiga buku ini kesemuanya tidak ada 
daftar pustaka maupun glosarium. Untuk ketepatan ejaan, masih terdapat kesalahan dalam penulisan misalnya kata "contents" menjadi "content", contoh lainnya adalah "find the indonesian!" padahal seharusnya adalah "Translate into Indonesia".

Komponen ketiga adalah keruntutan dan kesatuan gagasan, yang terdiri dari keutuhan makna dalam bab, sub bab dan paragraf dan ketautan antar bab, sub bab, paragraf dan kalimat. Secara umum kalimat memiliki makna dan kebertautan. Dalam kompetensi membaca bacaan yang tersedia dalam ketiga buku ini tidak lebih dari satu paragraf, dimana karena buku ini merupakan buku untuk kelas bawah. Dalam ketiga buku ini setiap buku dalam bab tidak memiliki kebertautan dan kesamaan makna dan juga tema. Minimnya materi yang diberikan oleh penulis, untuk buku KLS 3 lebih bagus dibandingkan KLS 1 dimana materi yang disajikan lebih banyak dan lebih lengkap.

\section{Kelayakan Penyajian}

Penyajian buku dinilai dari penyajian berdasarkan isi (materi) dan penyajian berdasarkan bahasa. Hasil penilaian sebagai berikut:

\begin{tabular}{|c|c|c|c|}
\hline \multirow[b]{2}{*}{ Sub komponen } & \multicolumn{3}{|c|}{ skor } \\
\hline & KLS1 & KLS 2 & KLS 3 \\
\hline \multicolumn{4}{|c|}{ Kelayakan Penyajian Berdasarkan Isi Materi } \\
\hline $\begin{array}{l}\text { Teknik } \\
\text { Penyajian }\end{array}$ & 6 & 8 & 11 \\
\hline $\begin{array}{l}\text { Penyajian } \\
\text { pembelajaran }\end{array}$ & 12 & 18 & 19 \\
\hline $\begin{array}{l}\text { Kelengkapan } \\
\text { Penyajian }\end{array}$ & 16 & 18 & 17 \\
\hline \multicolumn{4}{|c|}{ Kelayakan Penyajian Berdasarkan Bahasa } \\
\hline $\begin{array}{l}\text { Teknik } \\
\text { penyajian }\end{array}$ & 4 & 7 & 6 \\
\hline $\begin{array}{l}\text { Penyajian } \\
\text { pembelajaran }\end{array}$ & 12 & 17 & 16 \\
\hline $\begin{array}{l}\text { Kelengkapan } \\
\text { penyajian }\end{array}$ & 17 & 17 & 17 \\
\hline Total & 67 & 85 & 86 \\
\hline Persentase & 55,83 & 70.83 & 71,66 \\
\hline Rata-rata & & 79,33 & \\
\hline
\end{tabular}

Tabel 3. Daftar Hasil Analisis Buku Pelajaran Bahasa Inggris Kelas 1,2, dan 3 Berdasarkan Penyajian
Hasil penilaian penyajian buku berdasarkan isi bahasa dari ketiga buku ini adalah buku KLS 1 dengan total skor 67 dari $120(55,83)$ kategori baik. Untuk buku dengan kode KLS 2 dengan skor 85 dari $120(70,83)$ kategori amat baik dan buku yang terakhir ada buku dengan kode KLS 3 dengan total skor 86 dari $120(71,66)$ dengan kategori amat baik. Nilai rata-rata dari ketiga buku ini adalah 79.33. dari ketiga buku ini yang dalam kategori baik adalah buku KLS 1 sedangkan untuk kategori amat bagus ada pada buku adalah KLS 2 dan KLS 3.

Penilaian penyajian baik isi maupun bahasa terdiri dari 3 komponen. Komponen tersebut yaitu teknik penyajian, penyajian pembelajaran, dan kelengkapan penyajian. Teknik penyajian isi secara umum setiap buku tidak melihat keruntutan konsep dari yang mudah ke sukar, atau dari abstrak ke konkret. Dalam setiap buku ini mewakili keempat keterampilan yang harus dikuasai oleh siswa. Akan tetapi yang paling bagus dari ketiga buku ini adalah buku KLS 3. Konsistensi sistematika dalam ketiga buku ini sangat bagus dan selalu konsisten. Secara umum menunjukkan kekonsistenan sistematika yaitu adanya materi yang ringan, sedang dan sulit kemudian dilanjutkan dengan soal latihan. Sedangkan untuk kesiimbangan antar bab tidak dilakukan, karena banyak materi yang diajarkan dan materi yang seharusnya penting dan mendalam, hanya dibahas secara sekilas semata. Sebagai contoh pada buku KLS 1 chapter 3 dan chapter 6. Dimana dalam chapter 3 membahas angka hanya sebatas angka semata tanpa adanya materi yang lebih dalam lagi. Dan chapter 6 materinya tentang buah-buahan. Dalam chapter 6 ini membahas jenis-jenis buah kemudian berlanjut dengan latihan soal mentranslate.

Penyajian pembelajaran dalam buku KLS 2 dan 3 secara umum menggunakan ilustrasi yang menarik, akan tetapi dalam penyajiannya tidak banyak menggunakan variasi metode penyajian. Dalam buku KLS 2, ilustrasi tidak semenatik buku KLS 3, walaupun dari kedua buku ini tidak ada yang mencantumkan sumbernya. Sedangkan dalam kelengkapan penyajian, secatra umum buku ini hanya memiliki daftar isi untuk pendahuluan, glosarium dan daftra pustaka 
tidaklahada. Semuanya sama untuk ketiga buku ini.

\section{Kelayakan Kegrafisan}

Hasil penilaian kegrafisan dalam ketiga buku ini adalah sebagai berikut:

\begin{tabular}{|l|c|c|c|}
\hline \multirow{2}{*}{ Aspek } & \multicolumn{3}{|c|}{ Skor } \\
\cline { 2 - 4 } & KLS 1 & KLS2 & KLS 3 \\
\hline A. UKURAN BUKU \\
\hline Ukuran & 3 & 7 & 6 \\
\hline \multicolumn{3}{|l|}{ B. DESAIN KULIT BUKU } \\
\hline $\begin{array}{l}\text { Tata } \\
\text { Letak }\end{array}$ & 36 & 33 & 26 \\
\hline Tipografi & 23 & 31 & 24 \\
\hline $\begin{array}{l}\text { Ilustrasi } \\
\text { C. Desain Isi Buku }\end{array}$ & 8 & 9 & 4 \\
\hline $\begin{array}{l}\text { Tata } \\
\text { Letak }\end{array}$ & 70 & 67 & 50 \\
\hline Tipografi & 56 & 58 & 45 \\
\hline Ilustrasi & 23 & 23 & 12 \\
\hline Total & 219 & 228 & 167 \\
\hline Persentase & 86,9 & 90.4 & 66.26 \\
\hline
\end{tabular}

Tabel 4. Daftar Hasil Analisis Buku Pelajaran Bahasa Inggris Kelas 1,2 dan 3 Berdasarkan Kegrafikan

Terakhir untuk instrumen kegrafisan hasil penilaian adalah untuk buku KLS 1 total skor 219 dari 252 (86.9) dengan kategori amat baik, untuk buku KLS 2 total skor adalah 228 dari 252 (90.4) dengan kategori amat baik dan buku yang terakhir adalah KLS 3 dengan total scor 167 dari $252(66,26)$ dengan kategori baik. Secara umum ketiga buku ini layak untuk digunakan jika nilai kegrafisannya adalah 81.1.

\section{PEMBAHASAN}

Pembahasan dari hasil penilaian ketiga buku ini yang digunakan di Sekolah Minggu Buddha menunjukkan bahwa buku tersebut memiliki komponen isi dengan kategori baik dan amat baik. Adapun kategori baik ada pada buku KLS 1 dan amat baik ada pada buku KLS 2 dan buku KLS 3. Untuk komponen bahasa kategori cukup pada buku KLS 1 dan kategori baik untuk buku KLS 2 dan KLS 3. Pada komponen penyajian kategori baik ada pada buku KLS 1 dan amat baik ada pada buku KLS 2 dan buku KLS 3. Pada komponen kegrafisan ini sangat terbalik dimana kategori amat baik ada pada buku
KLS 1 dan KLS 2 sedangkan untuk buku KLS 3 mendapatkan kategori baik saja. Yang terakhir yaitu pada kategori wacana untuk buku KLS 1 dan KLS 2 dikategorikan cukup dan buku KLS 3 dikategorikan baik. Berikut ini adalah tabel hasil kelayakan dan keterbacaan buku pelajaran yang digunakan di SMB dhamma Panna Temanggung.

\begin{tabular}{|l|l|l|l|}
\hline $\begin{array}{l}\text { Komponen } \\
\text { penilaian }\end{array}$ & KLS 1 & KLS 2 & KLS3 \\
\hline Isi & baik & $\begin{array}{l}\text { Amat } \\
\text { baik }\end{array}$ & $\begin{array}{l}\text { Amat } \\
\text { baik }\end{array}$ \\
\hline Bahasa & cukup & baik & baik \\
\hline Penyajian & baik & $\begin{array}{l}\text { Amat } \\
\text { baik }\end{array}$ & $\begin{array}{l}\text { Amat } \\
\text { baik }\end{array}$ \\
\hline Grafik & $\begin{array}{l}\text { Amat } \\
\text { baik }\end{array}$ & $\begin{array}{l}\text { Amat } \\
\text { baik }\end{array}$ & baik \\
\hline Wacana & kurang & kurang & baik \\
\hline
\end{tabular}

Tabel 5. hasil kelayakan dan keterbacaan buku pelajaran Bahasa Inggris yang digunakan di SMB dhamma Panna Temanggung

Hal ini sejalan dengan hasil pengamatan dari pengamat kedua yaitu juga mengamatai ketiga buku tersebut. Hal ini dapat dilihat pada kelayakan isi, penyajian, bahasa, dan kegrafisan, serta tingkat keterbacaan wacana. Buku-buku tersebut telah dianalisi oleh peneliti yang hasilnya tidak memiliki perbedanan secara signifikan dengan pengamat kedua, pembahasannya adalah sebagai berikut ini. Sebuah buku dapat dikatakan baik dari segi materi apabila memperhatikan acuan yang lengkap, yaitu sesuai dengan kurikulum atau silabus yang disusunn, ilmu yang relevan, kemampuan kebutuhan bahasa (W. Harimasyah, Dkk. 2008). Dari hasil setiap buku penilaian kelayakan isi menunjukkan bahwa 1 buku menunjukkan kategori baik dan 2 buku menunjukkan kategori amat baik. Dimana ketiga buku ini isinya sudah relevan dengan SK dan KD. Hanya saja materi yang ada dalam buku ini tidaklah terlalu mendalam terutama untuk buku KLS 1 dan buku KLS 2, sedangkan untuk buku KLS 3 materinya lebih banyak bila dibandingkan dengan kedua buku itu. Adapun untuk latihan soal untuk buku KLS 1 kurang fungsional dimana soal-soal yang diberikan dapat dikategorikan sangat susah sekali untuk ukuran siswa kelas 1. Buku 
pelajaran setidaknya memiliki materi yang disajikan berasalkan dari lingkungan terdekat dan akrab dengan kehidupan sehari-hari untuk peserta didik (kontekstual), tetapi ada beberapa materi dari ketiga buku tersebut tidak mencerminkan kontekstualnya.

Pokok bahasan dari materi yang tepat tersebut hanya bermanfaat dan dapat dipahami siswa jika diuraikan dengan bahasa yang dapat dipahami oleh siswa. Oleh karena itu, dalam kriteria juga dikemukakan kriteria bahasa yang dipergunakan. Bahasa yang digunakan ditentukan oleh tingkat kemampuan bahas para siswa dan menggunakan bahasa yang standar. Maksud dari bahasa standar disini adalah kalimat yang digunakan efektif, terhindar dari makna ganda, sederhana, sopan, dan menarik (Tarigan \& Tarigan 2009). Akan tetapi pada penilaian kelayakan bahasa dilihat dari nilai rata-rata maupun nilai pada setiap buku memiliki kategori cukup dan baik. Kategori cukup disini untuk buku KLS 1 sedangkan baik untuk kode buku KLS 2 dan KLS 3. Dari ketiga buku ini perlu adanya beberapa revisi sesuai dengan tingkat perkembangan bahasa pada siswa dan standarnya sehingga buku ini layak untuk digunakan.

Jika buku telah mempunyai isi yang sesuai dengan tingkat kemampuan siswa, bahasa yang mudah dipahami, maka siswa akan memiliki keinginan untuk membacanya, diperlukannya penyajian yang menarik dari setiap buku ini. Menurut Tarigan \& Tarigan (2009) buku text yang baik adalah buku text yang dapat membuat siswaingin, mau, senang mengerjakan apa yang diinstruksikan dalam buku teks, maka tentunya akan menambah ketertarikan siswa dalam pembelajaran tersebut. Hal ini berkaitan dengan penyajian,adapun penyajian dilihat dariawal buku sampai akhir buku. Jika pendahuluan tidak ada ilutrasi yang menarik maka siswapun enggan membaca. Dari ketiga buku ini kesemuanya tidak ada pendahuluan sama sekali. Materi yang disajikan dari hal-hal yang sulit untuk selanjutnya siswapun enggan membacanya. Dari ketiga buku, materi disajikan dari yang mudah, kemudian berkembang ke sedang, dan yang terakhir ke sulit. Nilai menunjukkan bahwa kelayakan penyajian hanya dua buku yang memiliki kategori amat baik dalam penyajian yaitu buku KLS 2 dan KLS 3, sedangkan untuk kategori baik ada pada buku KLS 1. Dalam buku KLS 1 ini memiliki kategori baik saja karena dalam buku ini belum sepenuhnya memiliki keseimbangan antar bab dan materi yang disajikan sangat singakat dan juga sulit untuk siswa kelas 1.

Buku yang baik secara isipun harus memiliki fisik yang baik. Penampilan mendukung isi, tanpa penampilan yang baik siswa tidak akan tertarik untuk membacanya, dan tanpa isi yang baik, siswa tidak akan paham apa yang terkandung di dalam buku tersebut. Dari hasil penelitian ketiga buku yang diteliti sudah dapat dikategorikan buku yang menarik minat siswa dari segi fisik, mulai dari cover, ilustrasi, warna dan perwujudan setiap bab. Hal ini dibuktikan dari penelitian pada ketiga buku terhadap kegrafisan sudah dikategorikan amat baik untuk buku KLS 1 dan KLS 2, sedangkan untuk buku KLS 3 kategori baik. Tetapi betapapun menariknya atau aktualnya sebuah wacana dalam buku, tidak akan berarti bagi pembelajarannya apabila tidak sesuai dengan kemampuan bahasa dan perkembangan kognitifnya (W. Hermansyah 2008). Bahasa yang dimaksud dalam hal ini adalah ejaan yang digunakan serta tinghkat keterbacaannya. Banyak buku bacaan yang penyusunan kalimatnya tidak memperhatikan kebutuhan pembaca. Buku bacaan tersebut terlalu sulit atau terlalu mudah untuk dibaca. Ketiga buku yang digunakan di sekolah dasar inipun telah dihitung dengan pengukuran tingkat keterbacaan wacana yang hasilnya terlalu sukar untuk dipahami oleh siswa pada jenjang kelas bawah atau kelas 1,2 dan 3 .

Jadi pada dasarnya penelitian ini berkaitan dengan penelitian-penelitian sebelumnya yang menunjukkan bahwa buku harus memiliki kelayakan isi, bahasa, penyajian, dan kegrafisan. Buku pelajaranpun harus sesuai dengan tingkat keterbacaannya, agar dapat dijadikan sebagai sumber belajar yang dapat menunjang aktivitas, kreatifitas dan memenuhi kebutuhan kognitif para peserta didik. 


\section{KESIMPULAN}

Berdasarkan hasil penelitian yanga telah dilakukan dan juga telah dilakukan sebuah pembahasan, maka dapat diambil sebuah kesimpulan bahwa: dari segi kelayakan isi berdasarkan penduan instrumen BNSP, dari ketiga buku ini, kategori amat baik ada pada buku dengan kode KLS 2 dan KLS 3, sedangkan untuk kategori baik ada pada buku KLS 1. Berdasarkan panduan instrumen BNSP, standar kelayakan ditinjau dari segi kebahasaan menunjukkan bahwa buku yang baik dari segi bahasa ada pada buku KLS 2 dan juga KLS 3, untuk buku KLS 1 memiliki kategori cukup.

Dari segi penyajian buku berdasarkan isi bahasa menurut pandian isntrumen BNSP, dari ketiga buku ini 2 diantaranya memiliki kategori amat baik yaitu buku KLS 2 dan buku KLS 3 sedangkan untuk buku KLS 1 mendapatkan kategori baik. Dari segi kegrafisan berdasarkan panduan BNSP menunjukkan bahwa ketiga buku ini sudah memenuhi kategori kelayakn yang amat baik dengan urutan buku KLS 1, KLS 2 dan yang terakhir adaalh buku KLS 3 dengan kategori baik.

Pengukuran keterbacaan wacana menunjukkan bahwa ketiga buku Bahasa Inggris yang digunakan di SMB Dhamma Panna Temanggung kurang sesuai denghan jenjang kelas yang diajarkan. Terutama dalam hal ini ada pada buku KLS 1 dan juga buku KLS 2, sedangkan untuk buku KLS 3sudah lebih bagus dibandingan dari kedua buku tersebut.

\section{DAFTAR PUSTAKA}

1. Arikunto, Suharsini. 2010. Prosedur Penelitian Suatu Pendekatan Praktis. Jakarta : Rieka Cipta.

2. Ahmad Slamet, dkk. 1991. Pokok-pokok Materi Membaca dan Pengajarannya (Garis Besar Materi Tatar Membaca). Bandung: IKIP Bandung.

3. Harjasujana, Ahmad Slamet, dkk. 2005. Keterampilan Membaca. Jakarta: Depdiknas

4. Harjasujana, Ahmad Slamet, dkk. 2006. Pentingnya Kedudukan Membaca. Bandung: Pikiran Rakyat.
5. Hidayati, Nanik. 2005. Analisis Buku Biologi Sma Kelas X Semester I Berdasarkan Kurikulum 2004 Yang Banyak Digunakan Di SMA Negeri Kabupaten Batang. Universitas Negeri Semarang

6. Ika Kurniawati. 2015. Modul Pelatihan Pengembangan Bahan Belajar. (http://sumberbelajar.belajar.kemdikbud.g o.id), diakses tanggal 5 Agustus 2020.

7. Maharani, Sabrina. 2009. Cerdas Memilih Buku Panduan Bagi Calon Pembeli Buku. Yogyakarta: Mitra Pelajar

8. Moleong, Lexy J. 2007. Metodologi Penelitian Kualitatif. Bandung: PT Remaja Rosdakarya Offset.

9. Mudlofar, Ali. 2012. Aplikasi Pengembangan Kurikulum Tingkat Satuan Pendidikan dan Bahan Ajar dalam Pendidikan Islam, Jakarta: Rajawali Pers.

10. Muslich, Masnur. 2011. Text Book Writing: Dasar-Dasar Pemahaman, Penulisan, dan Pemakaian Buku Teks. Yogyakarta: Ar-Ruzz Media.

11. Muzakir. 2010. Penulisan Buku Teks yang Berkualitas (Artikel Jurnal Online).http://www.google.com/file.upi.e du/Direktori/FPBS/JUR._PER Diakses 10 Agustus 2020.

12. Nugroho, Adi. 2005. Analisis dan Perancangan Sistem Informasi Dengan Metodologi Berorientasi Obejek. Bandung: Penerbit Informatik.

13. Peraturan Menteri Pendidikan Nasional Nomor 11 Tahun 2005 Tentang Buku Pelajaran.

14. Prastowo, Andi. 2011. Panduan Kreatif Membuat Bahan Ajar Inovatif. Yogyakarta: Diva Press.

15. Sudrajat, Akhmad. 2015. Pengembangan bahan ajar. akhmadsudrajat.wordpress.com, diakses tanggal 5 Agustus 2020.

16. Supriadi, Dedi. 2001. Anatomi Buku Sekolah di Indonesia. Yogyakarta : Adicita Karya Nusa.

17. Susetyo. 2010. Penelitian Kuantitatif dan Penelitian Tindakan Kelas. Bengkulu: FKIP UNIB.

18. Tarigan, Henry Guntur dan Djago Tarigan. 2009. Telaah Buku Teks Bahasa Indonesia. Bandung: Angkasa 